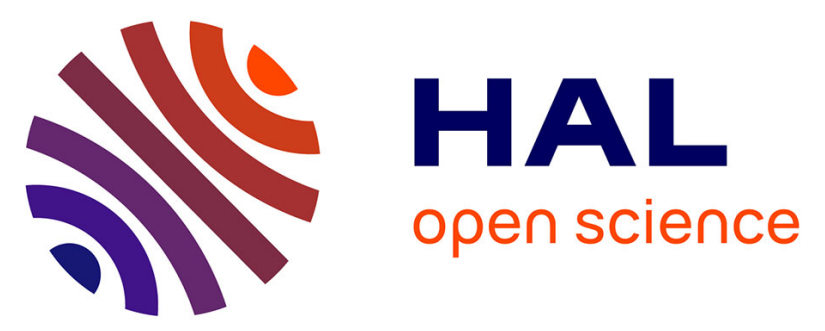

\title{
Palladium-catalyzed successive C-H bond arylations and annulations toward the pi-extension of selenophene-containing aromatic skeletons
}

Xinzhe Shi, Shuxin Mao, Thierry Roisnel, Henri Doucet, Jean-François Soulé

\section{- To cite this version:}

Xinzhe Shi, Shuxin Mao, Thierry Roisnel, Henri Doucet, Jean-François Soulé. Palladium-catalyzed successive $\mathrm{C}-\mathrm{H}$ bond arylations and annulations toward the pi-extension of selenophene-containing aromatic skeletons. Organic Chemistry Frontiers, 2019, 6 (14), pp.2398-2403. 10.1039/c9qo00218a . hal-02278420

HAL Id: hal-02278420

https://hal-univ-rennes1.archives-ouvertes.fr/hal-02278420

Submitted on 12 Sep 2019

HAL is a multi-disciplinary open access archive for the deposit and dissemination of scientific research documents, whether they are published or not. The documents may come from teaching and research institutions in France or abroad, or from public or private research centers.
L'archive ouverte pluridisciplinaire HAL, est destinée au dépôt et à la diffusion de documents scientifiques de niveau recherche, publiés ou non, émanant des établissements d'enseignement et de recherche français ou étrangers, des laboratoires publics ou privés. 


\title{
Palladium-Catalyzed Successive C-H Bond Arylations and Annulations toward the $\pi$ - Extension of Selenophene-Containing Aromatic Skeletons
}

\author{
Xinzhe Shi, Shuxin Mao, Thierry Roisnel, Henri Doucet* and Jean-François Soulé* \\ Univ Rennes, CNRS UMR6226, F-3500 Rennes, France henri.doucet@univ-rennes1.fr and jean-francois.soule@univ-rennes1.fr
}

A modular approach for the synthesis of planar $\pi$-extended selenium containing molecules from selenophene has been developed. Different combinations of $\mathrm{Pd}$-catalyzed desulfitative $\mathrm{C}-\mathrm{H}$ bond arylations with (2-bromo)arylsulfonyl chlorides and Pd-catalyzed intra- or/and inter-molecular $\mathrm{C}-\mathrm{H}$ bond arylations with aryl bromides allowed to extend the selenophene-containing aromatic skeleton at the $[b]-,[c]$ - or $[b: d]$-junctions to give phenanthro[b]selenophenes, phenanthro $[c]$ selenophenes or diphenanthro $[b: d]$ selenophenes

\section{Introduction}

Planar $\pi$-extended organic molecules are considered the next generation of charge carrier trasnporting materials for optoelectronic devices. ${ }^{1} \quad$ Several analogues containing an heteroaromatic unit such as thiophene, or pyrrole have been synthetized and have found number of applications as electronic components for the preparation of devices. ${ }^{2}$ Despite the recent interest of selenophenes as building blocks for the preparation of optoelectronic organic materials, ${ }^{3}$ only scarce examples of planar $\pi$-extended molecules containing Se atoms have been prepared. ${ }^{4}$ In 2016, Zeni et al prepared two phenanthroselenophenes in three steps via two electrophilic cyclizations as the key steps. ${ }^{5}$ Other methods involved the use of elemental selenium and multi-steps-synthesis, which often prevent the access to well-decorated $\pi$-extended selenophene derivatives bearing sensitive functional groups. ${ }^{6}$

Nowadays $\mathrm{C}-\mathrm{H}$ bond functionalization has emerged as a suitable alternative to other cross-coupling reactions owing its steps and atom economy and its broad functional group tolerance. $^{7}$ Interestingly, a more direct strategy enabling $\mathrm{C}-\mathrm{H}$ bond functionalization coupled with annulation reaction allowed to prepare planar $\pi$-extended organic molecules ${ }^{8}$ including sulfur-, ${ }^{9}$ nitrogen-,${ }^{10}$ or oxygen- analogues. ${ }^{11}$ However, to our knowledge, a protocol enabling successive $\mathrm{C}-\mathrm{H}$ bond arylations for the preparation of selenium-containing $\pi$ extended organic molecules was not reported yet. ${ }^{12}$ Indeed, only a few reports focused on the reactivity of selenophenes via transition metal-catalyzed $\mathrm{C}-\mathrm{H}$ bond functionalizations. In 2011, Mori, Koumura et al. reported the first examples of Pdcatalyzed $\alpha$-arylations of selenophenes using aryl iodides for the preparation of new dyes incorporated in photovoltaic cells. ${ }^{13}$ Later, Schneider and co-workers succeeded to generalize $\alpha$ arylation of selenophenes with other aryl halides (bromides and iodides). ${ }^{14}$ The arylation of heteroarenes at 6 -position is still more challenging. ${ }^{15}$ There are four main strategies to control the regioselectivity toward the C3 or C4 arylations of thiophenes: i) using a directing group, ${ }^{16}$ ii) using a specific catalytic system, ${ }^{17}$ iii) using $\mathrm{C} 2, \mathrm{C} 5$-disubstituted thiophenes ${ }^{18}$ or iv) using specific arylating sources (e.g., $\mathrm{ArB}(\mathrm{OH})_{2},{ }^{19} \mathrm{ArSiMe}_{3},{ }^{20}$ $\mathrm{ArSO}_{2} \mathrm{Cl}^{21}$ ). In 2017, our group achieved the first Pd-catalyzed $\beta$ arylation of selenophenes using $\mathrm{ArSO}_{2} \mathrm{Cl}^{22}$ We also demonstrated that well-decorated tetraarylated selenophenes could be obtained in good yields via successive $\mathrm{C}-\mathrm{H}$ bond arylations. Besides the switch of regioselectivity, Pd-catalyzed $\mathrm{C}-\mathrm{H}$ bond arylations with $\mathrm{ArSO}_{2} \mathrm{Cl}$ allowed orthogonal transformations owing their chemoselectivity with halogenated substrates. ${ }^{23}$ As a continuation of our research program dealing with the synthesis of heteroaromatic analogues of planar $\pi$ extended organic molecules, ${ }^{24}$ we became interested in the phenanthroselenophene series.

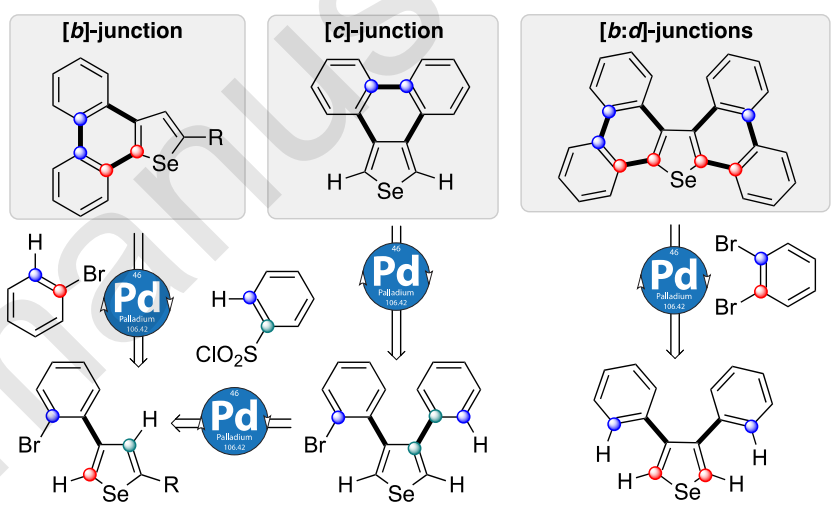

Figure 1. Unified Strategy for the Preparation of Phenanthroselenophenes

Our retrosynthetic analysis is outlined in Figure 2. Firstly, we planned to build phenanthro[b]selenophenes in two-operations via Pd-catalyzed desulfitative $\beta$-arylation with 2bromobenzenesulfonyl chlorides, followed by Pd-catalyzed $\alpha$ arylation coupled with annulation; while phenanthro $[c]$ selenophenes will be obtained via three consecutive $\mathrm{C}-\mathrm{H}$ bond arylations, namely $\mathrm{Pd}$-catalyzed desulfitative C3-arylation with 2-bromobenzenesulfonyl chlorides of selenophene followed by a second desulfitative C4arylation and intramolecular $\mathrm{C}-\mathrm{H}$ bond arylation. Finally, diphenanthro $[b: d]$ selenophenes will be synthetized from 3,4diarylselenophenes and 1,2-dibromobenzene via Pd-catalyzed double Pd-catalyzed $\alpha$-arylation coupled with annulation.

\section{Results}

Using our previous reaction conditions for the $\beta \mathrm{C}-\mathrm{H}$ bond arylation of selenophenes, ${ }^{22}$ we firstly prepared the 4-(2bromophenyl)selenophene intermediates 1-7 from 2arylselenophene derivatives and diversely substituted 2bromobenzenesulfonyl chlorides (Scheme 1). This unique regioselectivity might be due to $\mathrm{Pd}^{\prime \prime} / \mathrm{Pd}^{\prime \prime}$ catalytic cycle rather 
than $\mathrm{Pd} / \mathrm{Pd}$ " owing the fast oxidative addition of $\mathrm{ArSO}_{2} \mathrm{Cl}$ to $\mathrm{Pd}^{\text {II. }}{ }^{25}$ Notably, 2-arylated selenophenes were prepared from selenophene via $\mathrm{C}-\mathrm{H}$ bond arylation with aryl bromides using slightly modified literature procedures (see SI). ${ }^{14}$ In the presence of $10 \mathrm{~mol} \% \mathrm{Pd}(\mathrm{OAc})_{2}$ and 6 equivalents of base $\left(\mathrm{Li}_{2} \mathrm{CO}_{3}\right)$ in 1,4-dioxane, selenophenes substituted at $\mathrm{C} 2$-position by 4-chlorophenyl, 4-pyridyl, 4-tolyl or 1-naphtyl groups reacted with 2-bromobenzenesulfonyl chloride to afford the C2,C4diarylated selenophenes 1-4 in moderate to good yields, without $\mathrm{C}-\mathrm{Br}$ bond cleavage. The reactions tolerated substituents on the 2-bromobenzenesulfonyl chloride, such as 4-trifluoromethyl-, 4-fluoro-, or 3-trifluoromethyl and their coupling with 2-(4-chlorophenyl)selenophene afforded the 2,4diarylselenophenes 5-7 in 55-70\% yields. Compounds 8 and $\mathbf{9}$ were prepared via our reported procedure. ${ }^{22}$<smiles>[R]c1cc[se]c1</smiles>
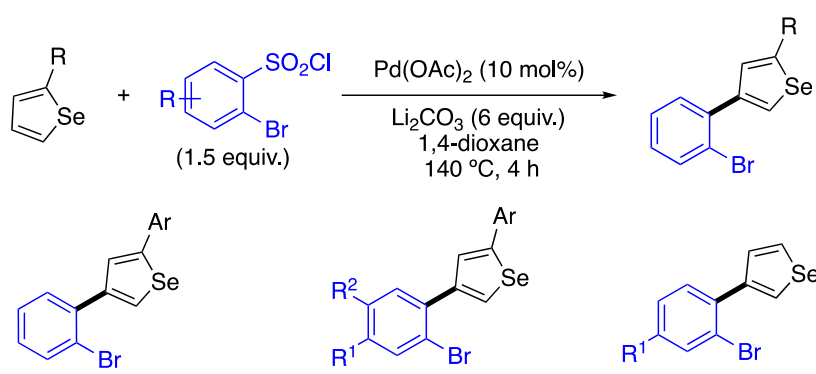<smiles>[R7]c1ccc(-c2cc[se]c2)c(Br)c1</smiles>

$\mathrm{Ar}$ $\mathrm{Ar}=4-\mathrm{Cl}-\mathrm{C}_{6} \mathrm{H}_{4}$ $\mathrm{R}^{1} \quad \mathrm{R}^{2}$ $\mathrm{CF}_{3} \mathrm{H} \quad 5 \quad 67 \%$ $\begin{array}{llll}\mathrm{F} & \mathrm{H} & \mathbf{6} & 70 \% \\ \mathrm{H} & \mathrm{CF} & 7 & 55 \%\end{array}$

4-Pyridinyl $258 \%$

4-Tolyl $379 \%$

1-Naphtyl $451 \%$

Scheme 1. Pd-Catalyzed Direct C4 Arylations of 2-Arylselenophenes Using 2Bromobenzenesulfonyl Chlorides

Then, with the selenophene derivatives 1-7 bearing a 2bromophenyl unit at $\mathrm{C} 4$ position in hand, we turned our attention to the second step, namely Pd-catalyzed tandem C5arylation with aryl bromides followed by annulation reaction to generate the phenanthroselenophenes in a one-pot two steps process (Scheme 2). Firstly, the reactivity of a set of aryl bromides was evaluated with 4-(2-bromophenyl)-2-(4chlorophenyl)selenophene (1) using a diphosphine-palladium catalyst $\left[\mathrm{PdCl}\left(\mathrm{C}_{3} \mathrm{H}_{5}\right)(\mathrm{dppb})\right]$ in the presence of KOPiv in DMA at 150 ㄷ. Reactions with electron-poor aryl bromides (e.g., 4bromobenzonitrile, 4-bromobenzotrifluoride, 4bromopropiophenone) with which the oxidative addition of the $\mathrm{C}-\mathrm{Br}$ bond to $\mathrm{Pd}(0)$ is faster than the $\mathrm{C}-\mathrm{Br}$ of the $\mathrm{C} 4$-phenyl unit of selenophene $\mathbf{1}$, gave $\mathrm{C} 5$-arylation followed by annulation reaction to afford the desired phenanthroselenophenes 10-12 in good yields. Notably, the $\mathrm{C}-\mathrm{Cl}$ bond was untouched during this tandem reaction. From a meta-substituted aryl bromide, the product $\mathbf{1 3}$ was isolated in moderate yield as a single regioisomer because the intramolecular $\mathrm{C}-\mathrm{H}$ bond arylation (annulation) occurred at the less hindered position. orthoSubstituted aryl bromides yielded $\mathbf{1 4}$ and $\mathbf{1 5}$. Notably, with 2bromobenzonitrile, the phenanthroselenophene 14 was obtained in a two-pots procedure. In the first instance, only the C5-arylated selenophene intermediate $\mathbf{1 4 i}$ was obtained due to the formation of non-active black palladium species. However, when this isolated intermediate was subjected to the same reaction conditions, namely $\mathrm{PdCl}\left(\mathrm{C}_{3} \mathrm{H}_{5}\right)(\mathrm{dppb})$ in the presence of KOPiv in DMA, we were pleased to find that cyclization reaction occurred to deliver the phenanthroselenophene 14. The use of larger amount of $\mathrm{PdCl}\left(\mathrm{C}_{3} \mathrm{H}_{5}\right)(\mathrm{dppb})$ affords the desired product 14 in one-pot, albeit in a lower yield. Next, we found that the nature of C2-aryl group on the selenophene exhibits a minor effect on the reactivity, as 4-tolyl, 1-naphtyl or 4-pyridyl C2substituted selenophenes 2-4 nicely reacted with 4bromobenzonitrile to give the phenanthroselenophenes 16-18 in good yields. Interestingly, the reaction was not limited to aryl bromides, and heteroaryl bromides could also be employed. The $\pi$-extended aromatic 19 containing both selenophene and thiophene units with a 2,2'-link was obtained in $45 \%$ yield from 1 and 2-acetyl-5-bromothiophene. Then, the influence of an additional substituent on the 4-aryl group of 4-(2-bromoaryl)-2(4-chlorophenyl)selenophenes was investigated. 4Arylselenophene derivatives $\mathbf{5}$ or $\mathbf{6}$ bearing trifluoromethyl or fluoro substituents at the meta position of the $\mathrm{C}-\mathrm{Br}$ bond, nicely reacted with 4-bromobenzonitrile to afford the phenanthroselenophenes 20 and $\mathbf{2 1}$ in $57 \%$ and $48 \%$ yield, respectively. This tandem $\mathrm{C} 5$-arylation-annulation was also successful with the selenophene derivative $\mathbf{7}$ bearing a trifluoromethyl at the para-position of the $\mathrm{C}-\mathrm{Br}$ bond, yielding the target product $\mathbf{2 2}$ in one step. However, it should be noted that reactions with electron-rich aryl bromides afforded complexes mixtures without the formation of the desired planar $\pi$-extended compounds.
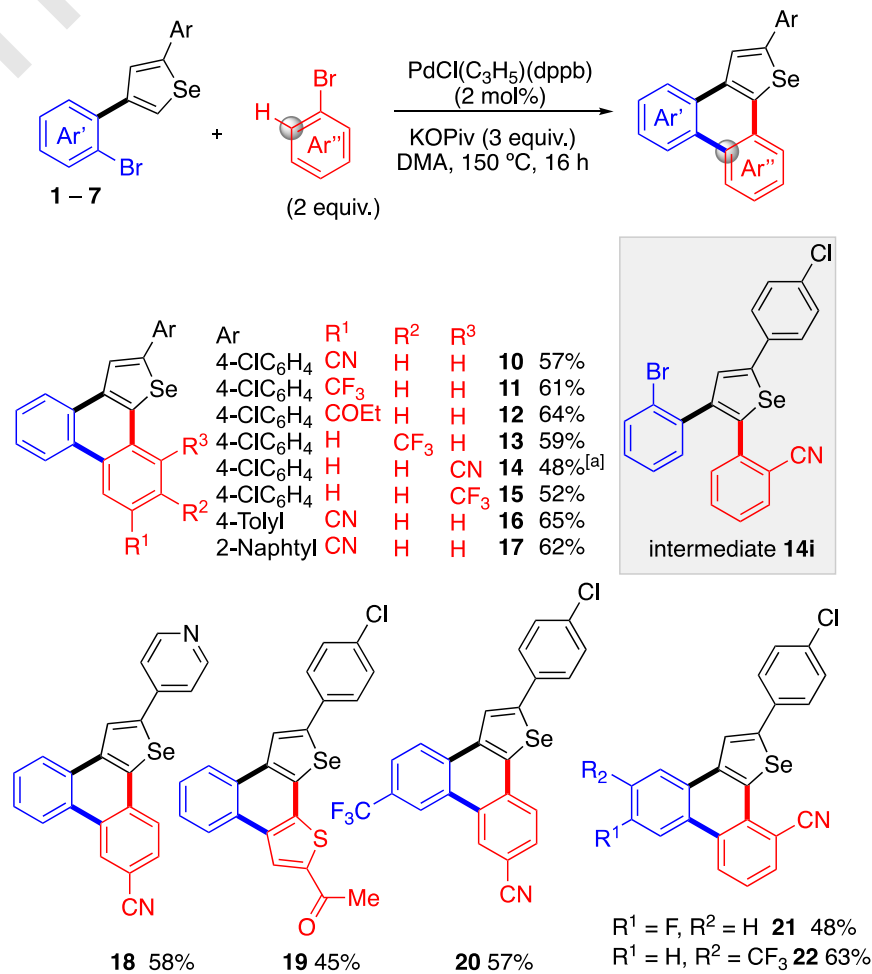

[a] Overall yield over two steps, intermediate 14i was isolated and reacted with $\mathrm{PdCl}\left(\mathrm{C}_{3} \mathrm{H}_{5}\right)(\mathrm{dppb})(2 \mathrm{~mol} \%)$, KOPiv (2 equiv.) in DMA at $150^{\circ} \mathrm{C}, 16 \mathrm{~h}$ 
Scheme 2. Pd-Catalyzed Tandem C5-Arylation - Annulation of 4-(2Bromophenyl)selenophene Derivatives 1-7 with Aryl Bromides for the Synthesis of Phenanthro $[b]$ selenophenes

Interestingly we found that using the same catalyst $\left[\mathrm{PdCl}\left(\mathrm{C}_{3} \mathrm{H}_{5}\right)(\mathrm{dppb})\right]$ in the presence of a larger amount of KOPiv

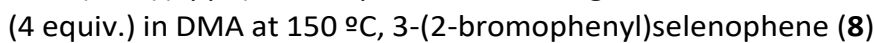
was diarylated at $\mathrm{C} 2$ and $\mathrm{C} 5$ positions with aryl bromides and that intramolecular $\mathrm{C}-\mathrm{H}$ bond arylation also occurred affording a one-pot protocol for the preparation of phenanthroselenophenes via a three-fold $\mathrm{C}-\mathrm{H}$ bond arylation (Scheme 3). From aryl bromides para-substituted by chloro, cyano, or propionyl groups, the seleno $\pi$-extended compounds 23-25 were obtained in a two-steps procedure after isolation of the non-cyclized 2,5-diaryl-4-(2-bromophenyl)selenophene intermediates 23i-25i. In contrast, aryl bromides parasubstituted by fluoro or trifluoromethyl groups underwent Pdcatalyzed three-fold direct arylations to afford the desired phenanthroselenophenes $\mathbf{2 6}$ and $\mathbf{2 7}$ in one-pot. Moreover, the use of 4-fluoro-1-iodobenzene instead of 1-bromo-4fluorobenzene gives a lower yield in the desired phenanthroselenophene 26. Reactions with 1-bromo-4-tertbutylbenzene or 4-iodotoluene did not resulted in the formation of the corresponding phenanthro $[b]$ selenophenes. 2-Bromobenzonitrile and 2-bromobenzotrifluoride were efficiently coupled with $\mathbf{8}$ to afford the fused selenophenes $\mathbf{2 8}$ and 29 in 51\% and 53\% yield, respectively. The structure of $\mathbf{2 9}$ was secured by X-Ray analysis. ${ }^{26}$ To prepare a $\pi$-extended aromatics containing both selenophene and pyridine units, an excess amount of base was required to neutralize the $\mathrm{HCl}$ salt of 4-bromopyridine, but the $\mathrm{C2}, \mathrm{C} 5$-diarylation reaction followed by annulation reaction proceeded in one-pot affording 30 in $56 \%$ yield.

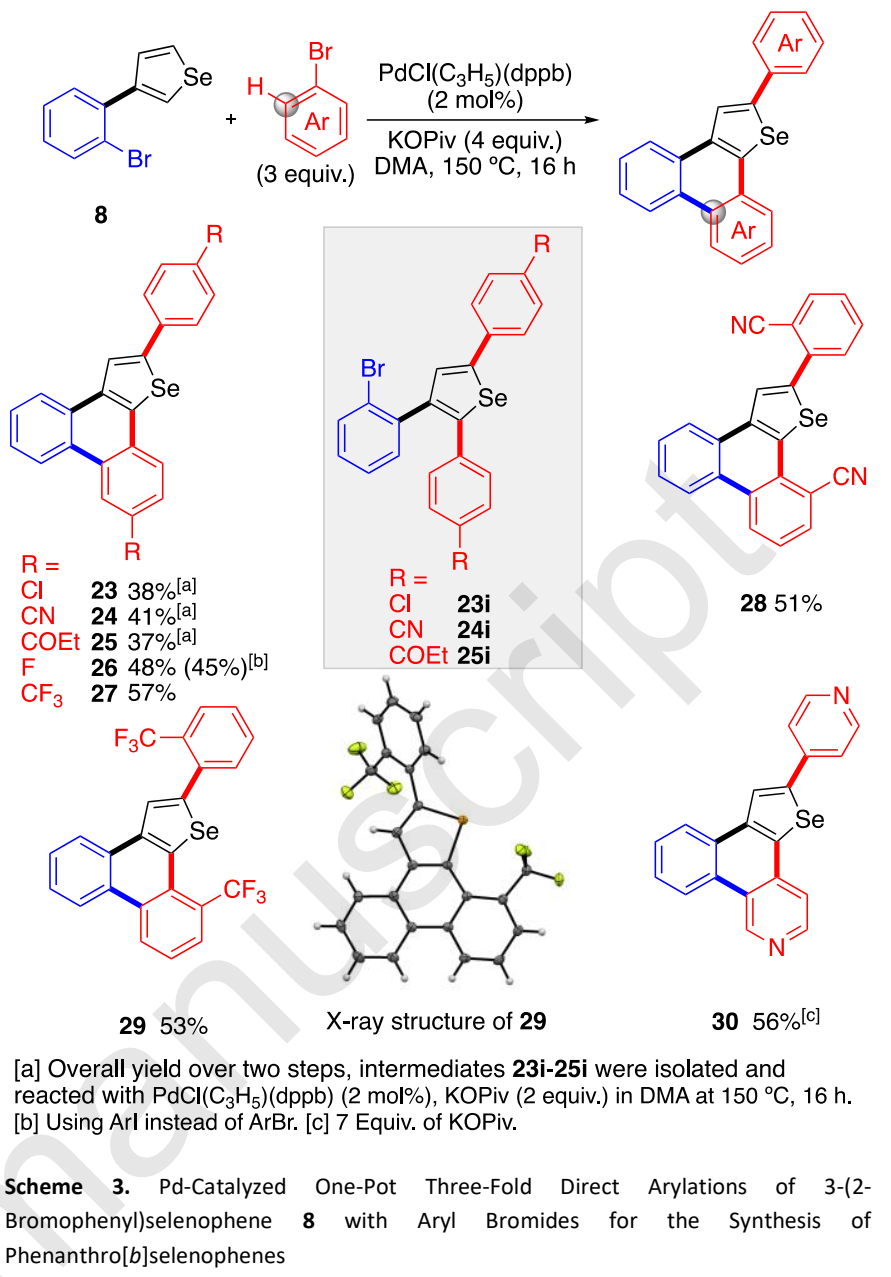

Then, from a mixture of 3-(2-bromophenyl)selenophene (8) and 4-CN-, 4-NO2- or 4-MeO-benzenesulfonyl chlorides the 3,4diarylated selenophenes 31-33 were obtained in moderate yields (Scheme 4). The introduction of a second aryl group at C4 position of 9 and 3-phenylselenophene was also achieved to give 34 and 35 in $32 \%$ and $49 \%$ yield, respectively. The second C4-arylation was more sluggish than the C3-arylation, but could be conducted using the same catalytic system provided that the reaction time was extended to $40 \mathrm{~h}$. Similarly, using this extended reaction time, the one-pot 3,4-diarylation of selenophene has been performed with 4(trifluoromethyl)benzenesulfonyl chloride, benzenesulfonyl chloride or 4-chlorobenzenesulfonyl chloride to give the symmetrical 3,4-diarylated selenophenes 36 and 37 in low yields. 

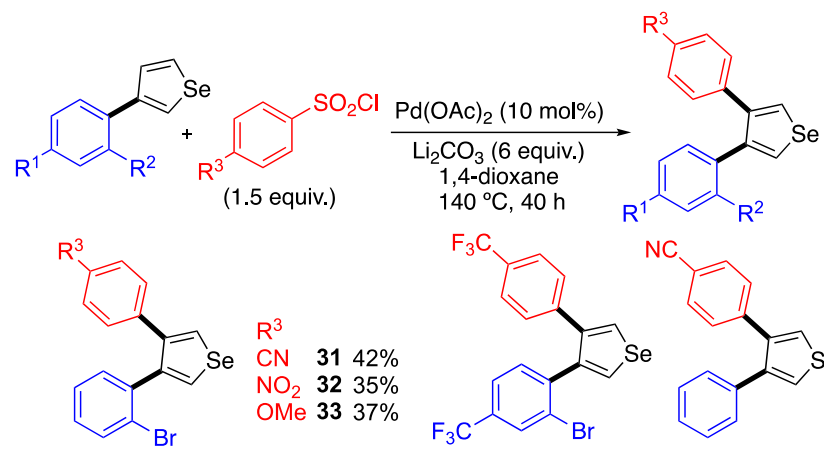

$\mathrm{F}_{3} \mathrm{C}$

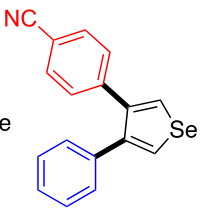

$3549 \%$

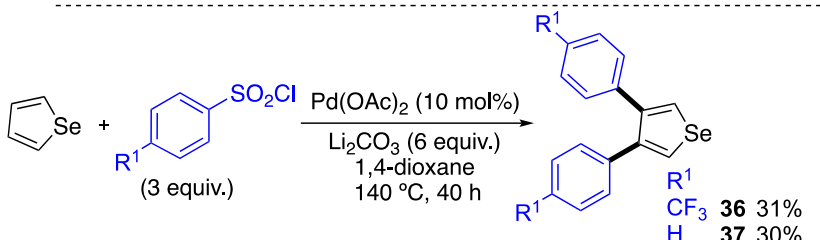

Scheme 4. Pd-Catalyzed Direct C4 Arylations of 3-Arylselenophenes (top) or C3,C4diarylation of Selenophene (bottom)

Having synthetized 3,4-diarylselenophenes, in which one of the aryl groups is a 2-bromoaryl, we investigated the Pd-catalyzed intramolecular $\mathrm{C}-\mathrm{H}$ bond arylation to access to phenanthro[c]selenophene structures (Scheme 5). The treatment of 31-35 by annulative conditions, namely 2 mol\% of $\mathrm{PdCl}\left(\mathrm{C}_{3} \mathrm{H}_{5}\right)(\mathrm{dppb})$ in the presence of KOPiv (4 equiv.) in DMA at 150 ㅇ $\mathrm{C}$ led to the phenanthro[c]selenophene derivatives 38-41 in good yields via a 6-membered ring formation. The reaction tolerated different functional group on the aryl unit such as $\mathrm{CN}$ $\mathrm{NO}_{2}$, OMe and $\mathrm{CF}_{3}$.

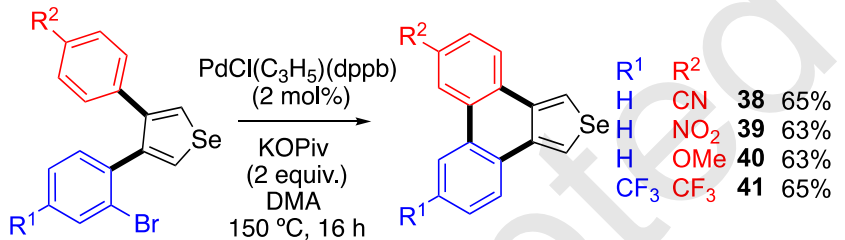

Scheme 5. Pd-Catalyzed Intramolecular C-H Bond Arylation of 3-(2-Bromoaryl)-4arylselenophenes for the Synthesis of Phenanthro[c]selenophene Derivatives

Later, we were pleased to find that diphenanthro $[b: d]$ selenophenes could be synthetized in a onepot operation from 3,4-diarylselenophenes and 3 equivalents of 1,2-dibromobenzene via double $\mathrm{Pd}$-catalyzed $\alpha$-arylation coupled with $\mathrm{C}-\mathrm{H}$ annulation. The symmetrical diphenanthro $[b: d]$ selenophenes $\mathbf{4 2}$ and $\mathbf{4 3}$ were isolated in moderate yields from 36 and 37 using $20 \mathrm{~mol} \%$ of $\mathrm{PdCl}\left(\mathrm{C}_{3} \mathrm{H}_{5}\right)(\mathrm{dppb})$ in the presence of KOPiv (5 equiv.) in DMA at 150 o. Interestingly, from unsymmetrical C3,C4diarylselenophene $\mathbf{3 5}$, prepared from selenophene via two successive desulfitative $\mathrm{C}-\mathrm{H}$ bond arylations, the diphenanthro[ $b: d]$ selenophene $\mathbf{4 4}$ was isolated in $42 \%$ yield.
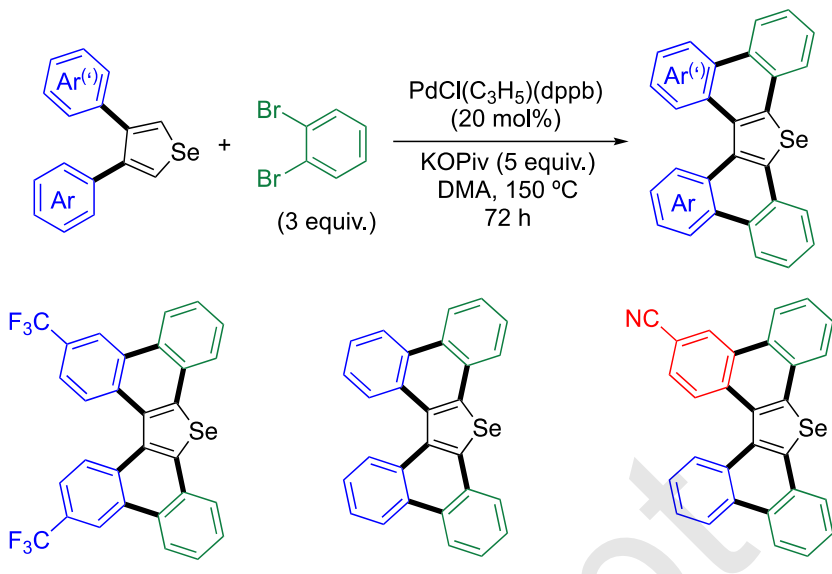

$4242 \%$

$4337 \%$

$4442 \%$

Scheme 6. Pd-Catalyzed One-Pot Four-Fold Direct Arylations of 3,4-Diarylselenophenes with 1,2-Dibromobenzene for the Synthesis of Diphenanthro[b:d]selenophenes

Finally, we explored the preparation of phenanthro[b]selenophenes from 2,4-diarylselenophenes (Scheme 7). From 2-(4-chlorophenyl)selenophene, Pdcatalyzed desulfitative arylation using benzenesulfonyl chloride afforded the 2,4-diarylselenophene $\mathbf{4 5}$ in 63\% yield. Then, in the presence of 1,2-dibromobenzene, $\mathrm{C} 5-\mathrm{H}$ bond arylation followed by annulation reaction gives the desired phenanthro $[b]$ selenophene $\mathbf{4 6}$ in $65 \%$ yield using 20 mol\% of $\mathrm{PdCl}\left(\mathrm{C}_{3} \mathrm{H}_{5}\right)(\mathrm{dppb})$ associated with KOPiv (5 equiv.) in DMA at

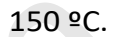
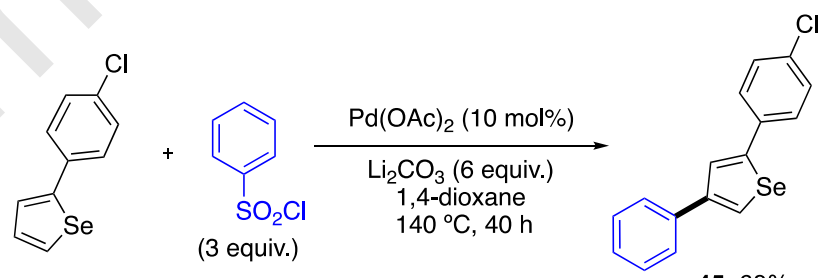

$4563 \%$

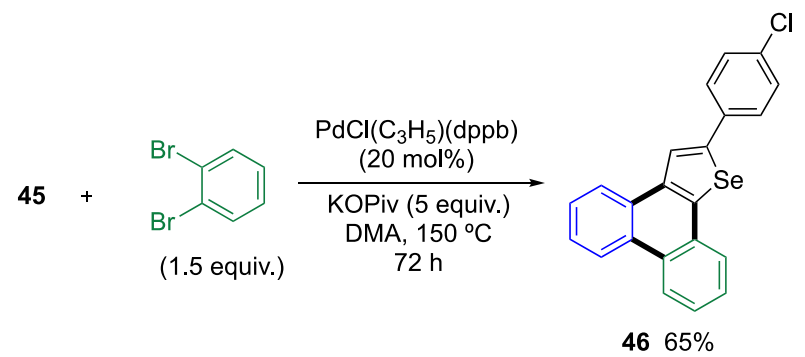

Scheme 7. Synthesis of a Phenanthro[b]selenophene via Pd-Catalyzed C4 Desulfitative arylation followed by One-Pot Two-Fold Direct Arylation of a 2,4-Diarylselenophene with 1,2-Dibromobenzene

\section{Conclusions}

In summary, we have achieved the synthesis of a wide diversity of well-decorated $\pi$-extended aromatics containing selenium atom from selenophene using the combination of three to six $\mathrm{C}-\mathrm{H}$ bond arylations. The key step was the introduction of (2bromo)aryl group(s) at $\beta$-position of selenophenes using Pdcatalyzed desulfitative arylation with (2-bromo)arylsulfonyl 
chorides. Then, Pd-catalyzed one-pot tandem $\mathrm{C}-\mathrm{H}$ direct arylations of selenophene rings at $\alpha$-position with aryl bromides followed by annulation reactions afforded phenanthro[b]selenophenes. In contrast, using a second Pdcatalyzed desulfitative arylation at $\beta^{\prime}$-position of selenophenenes followed by a cyclization reaction, phenanthro[c]selenophenes were obtained. Rapid construction to exotic scaffolds such as diphenanthro[b:d]selenophenes has also been achieved by double Pd-catalyzed $\alpha$-arylation annulation reaction.

\section{Conclusions}

The conclusions section should come in this section at the end of the article, before the acknowledgements.

\section{Conflicts of interest}

There are no conflicts to declare

\section{Acknowledgements}

We are grateful to the ANR (ANR-16-CE07-0001) for a grant to X.S.

\section{Notes and references}

1. a) M. D. Watson, A. Fechtenkötter and K. Müllen, Chem. Rev., 2001, 101, 1267-1300; b) J. Wu, W. Pisula and K. Müllen, Chem. Rev., 2007, 107, 718-747.

2. M. Stępień, E. Gońka, M. Żyła and N. Sprutta, Chem. Rev., 2017, 117, 3479-3716.

3. a) S. Yamaguchi, C. Xu and T. Okamoto, Pure Appl. Chem., 2006, 78, 721-730; b) T. Yamamoto and K. Takimiya, J. Am. Chem. Soc., 2007, 129, 2224-2225; c) J. Hollinger, D. Gao and D. S. Seferos, Isr. J. Chem., 2014, 54, 440-453.

4. a) W. Jiang, H. Qian, Y. Li and Z. Wang, J. Org. Chem., 2008, 73, 7369-7372; b) R. K. Gupta, S. K. Pathak, B. Pradhan, M. Gupta, S. K. Pal and A. A. Sudhakar, ChemPhysChem, 2016, 17, 859-872; C) D. Meng, H. Fu, C. Xiao, X. Meng, T. Winands, W. Ma, W. Wei, B. Fan, L. Huo, N. L. Doltsinis, Y. Li, Y. Sun and Z. Wang, J. Am. Chem. Soc., 2016, 138, 10184-10190; d) G. R. Kiel, S. C. Patel, P. W. Smith, D. S. Levine and T. D. Tilley, J. Am. Chem. Soc., 2017, 139, 18456-18459.

5. T. B. Grimaldi, G. Lutz, D. F. Back and G. Zeni, Org. Biomol. Chem., 2016, 14, 10415-10426.

6. a) R. F. Schumacher, A. R. Rosario, M. R. Leite and G. Zeni, Chem. Eur. J., 2013, 19, 13059-13064; b) E. Paegle, S. Belyakov and P. Arsenyan, Eur. J. Org. Chem., 2014, 2014, 3831-3840; c) R. P. Pistoia, J. A. Roehrs, D. E. Back and G. Zeni, Adv. Synth. Catal., 2015, 357, 3655-3665; d) E. Paegle, I. Domracheva, B. Turovska, M. Petrova, I. Kanepe-Lapsa, A. Gulbe, E. Liepinsh and P. Arsenyan, Chem. Asian J., 2016, 11, 1929-1938; e) G. Perin, J. A. Roehrs, P. S. Hellwig, G. Stach, T. Barcellos, E. J. Lenardao, R. G. Jacob and E. Q. Luz, Chemistryselect, 2017, 2, 4561-4566; f) K. K. Casola, M. R. Gomes, D. F. Back and G. Zeni, J. Org. Chem., 2018, 83, 6706-6718; g) A. Skhiri, R. Ben Salem, J.-F. Soulé and H. Doucet, ChemCatChem, 2017, 9, 2895-2913.

7. a) T. W. Lyons and M. S. Sanford, Chem. Rev., 2010, 110, 1147$1169 ;$ b) R. Rossi, F. Bellina, M. Lessi and C. Manzini, Adv. Synth.
Catal., 2014, 356, 17-117; c) M. Zhang, Y. Zhang, X. Jie, H. Zhao, G. Li and W. Su, Org. Chem. Front., 2014, 1, 843-895; d) K. Gao and N. Yoshikai, Acc. Chem. Res., 2014, 47, 1208-1219; e) K. Hirano and M. Miura, Chem. Lett., 2015, 44, 878-873; f) J. Kalepu, P. Gandeepan, L. Ackermann and L. T. Pilarski, Chem. Sci., 2018, 9, 4203-4216; g) F. F. Khan, S. K. Sinha, G. K. Lahiri and D. Maiti, Chem. Asian J., 2018, 13, 2243-2256.

8. a) M. Iwasaki, S. Lino and Y. Nishihara, Org. Lett., 2013, 15, 53265329; b) N.-h. Chang, X.-c. Chen, H. Nonobe, Y. Okuda, H. Mori, K. Nakajima and Y. Nishihara, Org. Lett., 2013, 15, 3558-3561; c) H. Mori, X.-c. Chen, N.-h. Chang, S. Hamao, Y. Kubozono, K. Nakajima and Y. Nishihara, J. Org. Chem., 2014, 79, 4973-4983; d) M. Iwasaki, Y. Araki, S. lino and Y. Nishihara, J. Org. Chem., 2015, 80, 9247-9263; e) B. P. Mathew, H. J. Yang, J. Kim, J. B. Lee, Y.-T. Kim, S. Lee, C. Y. Lee, W. Choe, K. Myung, J.-U. Park and S. Y. Hong, Angew. Chem. Int. Ed., 2017, 56, 5007-5011.

9. K. Saito, P. K. Chikkade, M. Kanai and Y. Kuninobu, Chem. Eur. J., 2015, 21, 8365-8368.

10. a) S. K. Bhunia, A. Polley, R. Natarajan and R. Jana, Chem. Eur. J., 2015, 21, 16786-16791; b) H. Kitano, W. Matsuoka, H. Ito and K. Itami, Chem. Sci., 2018; c) X. Shi, J.-F. Soulé and H. Doucet, J. Org. Chem., 2017, 82, 3886-3894.

11. a) X. Wu, Y. Yang, J. Han and L. Wang, Org. Lett., 2015, 17, 56545657; b) J. Côté and S. K. Collins, Synthesis, 2009, 2009, 14991505.

12. S.-Y. Chen, Y.-C. Pao, S. K. Sahoo, W.-C. Huang, Y.-Y. Lai and Y.-J. Cheng, Chem. Commun., 2018, 54, 1517-1520.

13. S. Tamba, R. Fujii , A. Mori, K. Hara and N. Koumura, Chem. Lett., 2011, 40, 922-924.

14. D. S. Rampon, L. A. Wessjohann and P. H. Schneider, J. Org. Chem., 2014, 79, 5987-5992.

15. C. B. Bheeter, L. Chen, J.-F. Soulé and H. Doucet, Catal. Sci. Technol., 2016, 6, 2005-2049.

16. a) T. Okazawa, T. Satoh, M. Miura and M. Nomura, J. Am. Chem. Soc., 2002, 124, 5286-5287; b) R. Padmavathi, R. Sankar, B. Gopalakrishnan, R. Parella and S. A. Babu, Eur. J. Org. Chem., 2015, 2015, 3727-3742.

17. S. Yanagisawa, K. Ueda, H. Sekizawa and K. Itami, J. Am. Chem. Soc., 2009, 131, 14622-14623.

18. A. L. Gottumukkala and H. Doucet, Adv. Synth. Catal., 2008, 350, 2183-2188.

19. S. Kirchberg, S. Tani, K. Ueda, J. Yamaguchi, A. Studer and K. Itami, Angew. Chem. Int. Ed., 2011, 50, 2387-2391.

20. K. Funaki, T. Sato and S. Oi, Org. Lett., 2012, 14, 6186-6189.

21. a) K. Yuan and H. Doucet, Chem. Sci., 2014, 5, 392-396; b) A. Hfaiedh, K. Yuan, H. Ben Ammar, B. Ben Hassine, J.-F. Soulé and H. Doucet, ChemSusChem, 2015, 8, 1794-1804.

22. A. Skhiri, R. B. Salem, J.-F. Soulé and H. Doucet, Chem. Eur. J., 2017, 23, 2788-2791.

23. a) A. Skhiri, A. Beladhria, K. Yuan, J.-F. Soulé, R. Ben Salem and H. Doucet, Eur. J. Org. Chem., 2015, 4428-4436; b) For a review on reactity of halo-substituted benzenesulfonyls and benzenesulfinates in cross-coupling reactions, see: $\mathrm{H}$. Li, A. Sasmal, X. Shi, J.-F. Soulé and H. Doucet, Org. Biomol. Chem., 2018, 16, 4399-4423.

24. W. Hagui, N. Besbes, E. Srasra, T. Roisnel, J.-F. Soulé and H. Doucet, Org. Lett., 2016, 18, 4182-4185.

25. For the formation of $\mathrm{Pd}^{\mathrm{IV}}$ via oxidative addition of $\mathrm{ArSO}_{2} \mathrm{Cl}$ to Pd", see: X. Zhao and V. M. Dong, Angew. Chem. Int. Ed., 2011, 50, 932-934.

26. CCDC 1866413 